\title{
A CHILD WITH DENSE DEPOSIT DISEASE AND DECREASED CLASSIC COMPLEMENT PATHWAY ACTIVITY
}

\author{
Ivana Trutin ${ }^{1}$, Lea Oletić ${ }^{1}$, Danica Galešić Ljubanovićé, \\ Daniel Turudić ${ }^{4}$ and Danko Milošević 3,4
}

${ }^{1}$ Department of Pediatrics, Sestre milosrdnice University Hospital Centre, Zagreb, Croatia;

${ }^{2}$ Division of Renal Pathology and Electron Microscopy, Department of Pathology,

Dubrava University Hospital, Zagreb Croatia;

${ }^{3}$ University of Zagreb, School of Medicine, Zagreb, Croatia;

${ }^{4}$ Zagreb University Hospital Centre, Zagreb, Croatia

SUMMARY - We report a rare case of nephritic syndrome underlying dense deposit disease (DDD) with alternative complement pathway dysfunction explained with both $\mathrm{C} 3$ nephritic factor $(\mathrm{C} 3 \mathrm{NeF})$ antibodies and DDD associated polymorphism of factor $\mathrm{H}$. An 8-year-old boy presented with macroscopic hematuria, hypertension and periorbital edema followed by persistently low $\mathrm{C} 3$ during the 8-week follow-up. Positive C3 staining on immunofluorescence microscopy, supported by dense deposits within the glomerular basement membrane on electron microscopy, confirmed the diagnosis of DDD. Preliminary tests for complement activation showed decreased classic pathway and deficient alternative complement pathway, as well as slightly positive $\mathrm{C} 3 \mathrm{NeF}$, supporting the diagnosis of DDD. Genetic analysis revealed a polymorphism of the complement factor $\mathrm{H}$ gene with an increased risk of developing DDD. Supportive therapy led to satisfactory recovery of renal function and normalization of $\mathrm{C} 3$. Given the poor prognosis of the disease, proper approach to such specific glomerulopathy is important to avoid or at least slow down progression to end-stage renal disease.

Key words: Dense deposit disease; C3 glomerulopathy; Children; Nephritic syndrome

\section{Introduction}

C3 glomerulopathy $(\mathrm{C} 3 \mathrm{G})$ is a rare kidney disease caused by abnormal complement activation consisting of two entities, dense deposit disease (DDD) and C3 glomerulonephritis $(\mathrm{C} 3 \mathrm{GN})^{1,2}$. Proteinuria, hematuria, acute nephritic/nephrotic syndrome, or even acute renal failure and low $\mathrm{C} 3$ levels in a child indicate the possibility of DDD. Complement dysregulation often found in $\mathrm{C} 3 \mathrm{G}$ is due to the $\mathrm{C} 3$ nephritic

Correspondence to: Ivana Trutin, $M D$, Department of Pediatrics, Sestre milosrdnice University Hospital Centre, Vinogradska c. 29, HR-10000 Zagreb, Croatia

E-mail: ivana.trutin@gmail.com

Received March 24, 2020, accepted June 8, 2020 factor $(\mathrm{C} 3 \mathrm{NeF})$ antibody directed against alternative pathway C3 convertase leading to uncontrolled complement activation ${ }^{1}$. Recent studies point to a certain type of $\mathrm{C} 3 \mathrm{G}$ with structurally abnormal complement factor $\mathrm{H}$-related (CFHR) proteins ${ }^{3}$. Factor $\mathrm{H}$ (CFR) is a plasma glycoprotein that down-regulates complement through preventing assembly and facilitating decay of the alternative pathway C3 convertase, and has a role in the prevention of complement activation ${ }^{4}$.

This is a report of a rare and educative case of glomerulopathy with persistently low $\mathrm{C} 3$ levels that appeared to be driven by overactivation of the alternative complement pathway in association with both $\mathrm{C} 3 \mathrm{NeF}$ antibodies and DDD associated polymorphism of factor $\mathrm{H}$. 


\section{Case Report}

A healthy 8-year-old boy with a negative family history of kidney disease had a sudden onset of macroscopic hematuria, hypertension and periorbital edema.

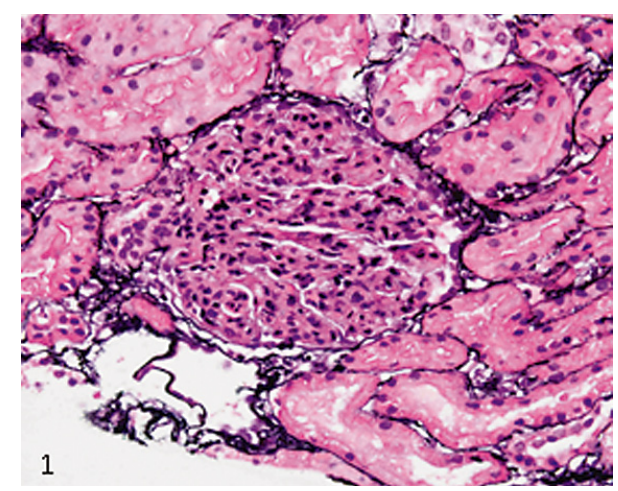

Fig. 1. Glomerulus with global endocapillary bypercellularity (Jones, X400).

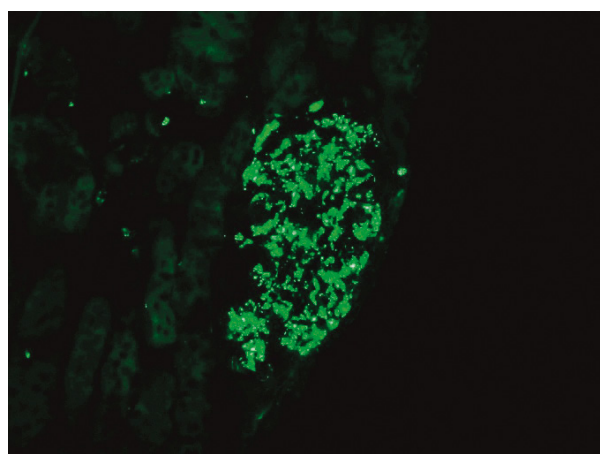

Fig. 2. Positive immunofluorescence for $C 3(2+)$ (DIF, X400).
Laboratory workup showed slightly elevated serum urea $(10.7 \mathrm{mmol} / \mathrm{L})$, normal creatinine $(87 \mu \mathrm{mol} / \mathrm{L})$, low serum protein $(62 \mathrm{~g} / \mathrm{L})$ and albumin $(33.4 \mathrm{~g} / \mathrm{L})$, as well as proteinuria $\left(1.69 \mathrm{~g} / 24 \mathrm{~h} ; 74.2 \mathrm{mg} / \mathrm{m}^{2} / \mathrm{h}\right)$, albuminuria $(1096 \mathrm{mg} / 24 \mathrm{~h})$ and urine casts. The glomerular filtration rate (GFR) measured by Schwartz formula was decreased $\left(80.2 \mathrm{~mL} / \mathrm{min} / 1.73 \mathrm{~m}^{2}\right)$. Initial C3 was low $(<0.110 \mathrm{~g} / \mathrm{L})$, along with normal C4 (0.30 $\mathrm{g} / \mathrm{L})$. ASO-titer was slightly elevated $(654 \mathrm{UI} / \mathrm{mL})$. Antinuclear antibody (ANA) and anti-neutrophil cytoplasmic antibody (ANCA) were negative, and so were serologic tests for hepatitis $\mathrm{C}$ and $\mathrm{B}$. Ultrasound examination showed normal appearance of the kidneys and urinary tract. Diagnostic kidney biopsy was performed after persistently low $\mathrm{C} 3$ during the 8-week follow-up. Out of 10/32 glomeruli, segmental or global endocapillary hypercellularity was found alongside mesangial hypercellularity (32/32) (Fig. 1). C3 immunofluorescence was positive $(2+)$ in the mesangium and peripheral capillary loop (Fig. 2). IgG, IgA, IgM, $\mathrm{C} 4, \mathrm{C} 1 \mathrm{q}$, kappa and lambda staining were negative. Electron microscopy showed dense deposits within the glomerular basement membrane (GBM) (Figs. 3-5). Based on prolonged and diminished serum $\mathrm{C} 3$ activity, preliminary tests for complement activation were performed. A reduced total complement activity (alternative pathway) of 3\% and total complement activity (classic pathway, hemolytic test) of $43 \mathrm{CH} 50 /$ $\mathrm{mL}$ were found. During treatment, decreased classic pathway and deficient alternative pathway were observed. $\mathrm{C} 3 \mathrm{NeF}$ was slightly positive, supporting the
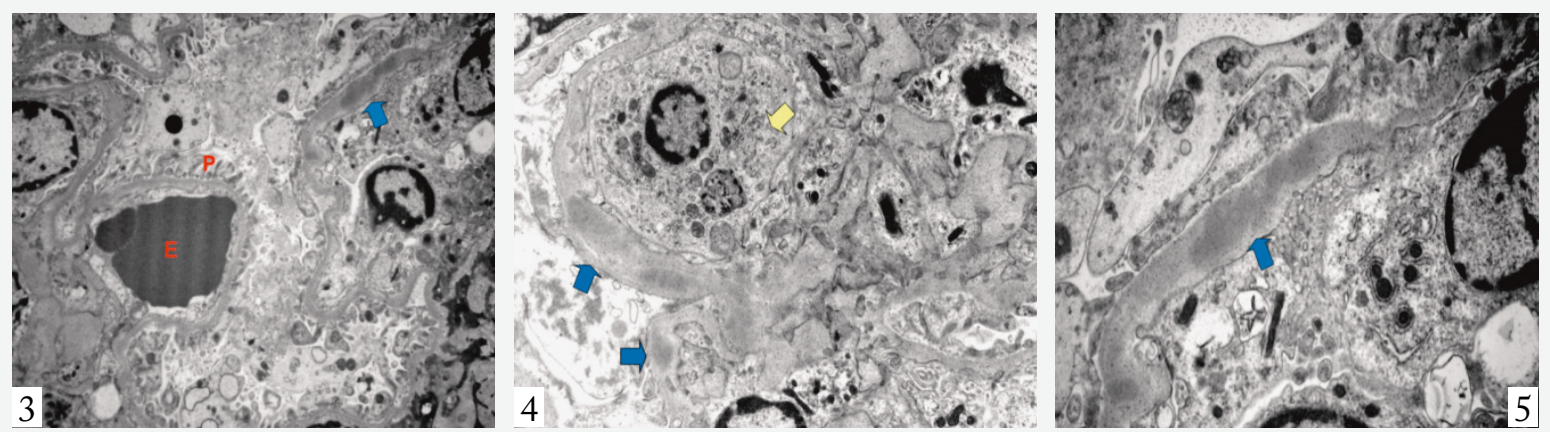

Fig. 3. Electron-dense deposits in glomerular basement membrane (blue arrow) (EM, X6000). $\mathrm{E}=$ red blood cell $; \mathrm{P}=$ podocyte

Fig. 4. Electron-dense deposits in glomerular basement membrane (blue arrows); inflammatory cell in the capillary lumen (yellow arrow) (EM, X10000).

Fig. 5. Electron-dense deposits in glomerular basement membrane (blue arrows) (EM, X15000). 
diagnosis of DDD. Genetic analysis found a homozygote for the rare allelic risk factor $\mathrm{H}, \mathrm{H} 402$, reported as a risk factor for the development of DDD.

\section{Outcome and follow-up}

The child recovered completely after receiving only supportive therapy (Fig. 6). During the follow-up, he was treated with antihypertensive therapy with strict control of blood pressure and angiotensin-converting enzyme inhibitors to reduce proteinuria. Fluid restriction and specific dietary regimen were applied for 2 weeks, antihypertensive therapy for only one week, and a diuretic (furosemide) was administered only once upon admission to the hospital. Initially, the cause of the disease was thought to be postinfectious glomerulonephritis, so antibiotic treatment was administered for 10 days. $\mathrm{C} 3$ and albuminuria returned to normal after approximately 2.5 months. Described therapy led to satisfactory recovery of renal function and normalization of $\mathrm{C} 3$. After 4 months, only microscopic he- maturia remained. At one-year follow-up, the child still had normal renal function.

\section{Discussion}

Dense deposit disease, a subtype of $\mathrm{C} 3 \mathrm{G}$, is a rare disease in children with progression towards end-stage renal disease within 10 years of initial diagnosis in about $50 \%$ of affected children, with common recurrence after kidney transplantation ${ }^{5,6}$. Our patient fits well within the previously reported children with this disease $^{5}$. Although in our patient immunofluorescence microscopy was strongly suggestive of $\mathrm{C} 3 \mathrm{G}$, the true nature of the disease was only established by electron microscopy with characteristic dense deposits.

Clinical course and low $\mathrm{C} 3$ can also be found in postinfectious glomerulonephritis, but in our case, it was causally associated with DDD. Decreased classic complement pathway and deficient alternative pathway are expected in DDD in accordance with its pathogenesis ${ }^{4}$.
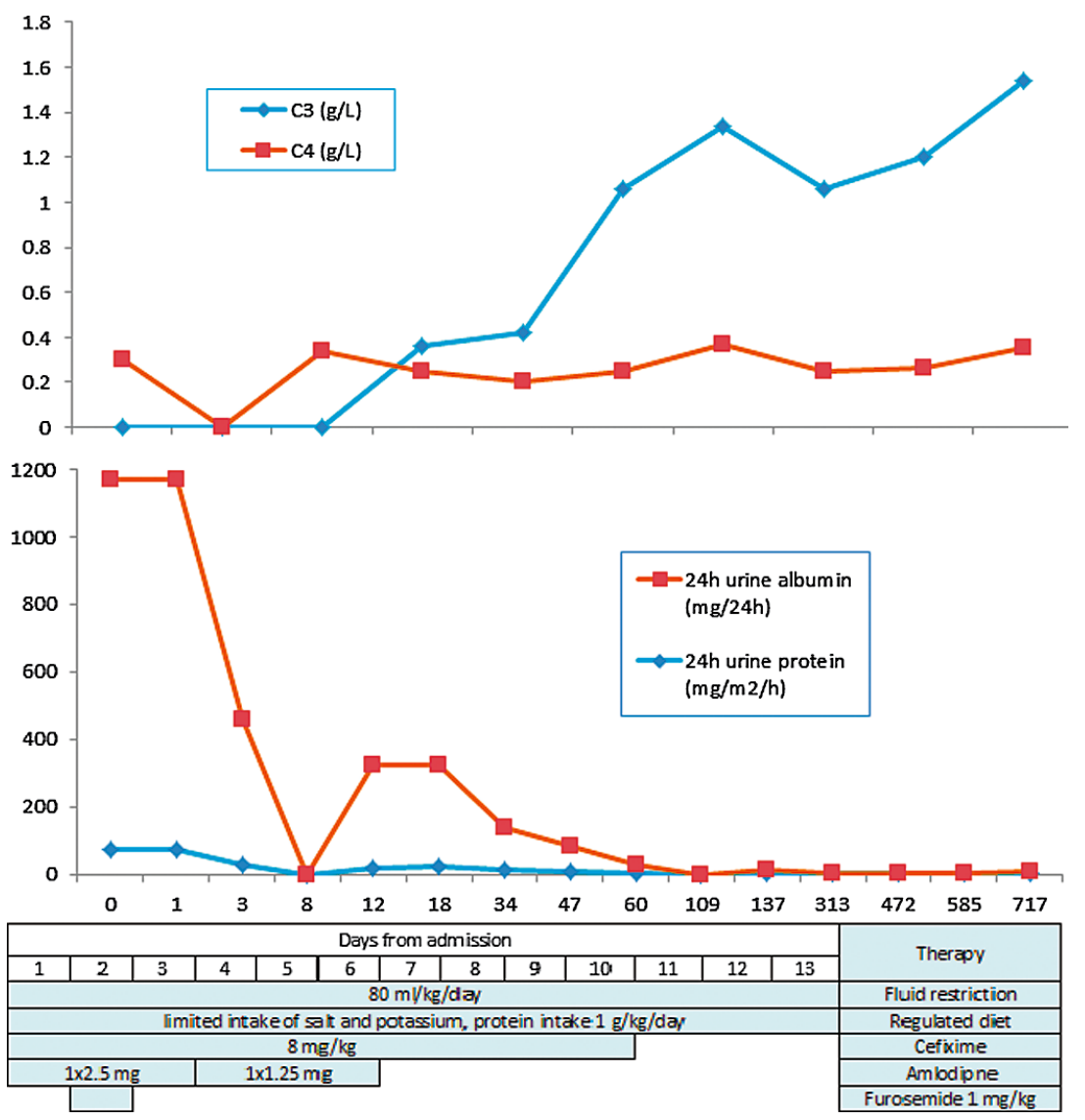

Fig. 6. Laboratory and treatment follow-up. 
About $80 \%$ of DDD patients, as well as our patient, are positive for $\mathrm{C}_{3} \mathrm{NeF}^{7}$. We did not find positive $\mathrm{C} 3 \mathrm{NeF}$ with partial lipodystrophy, which is often described as an extrarenal manifestation of $\mathrm{C}_{3} \mathrm{G}^{8}$.

The etiology of DDD has not yet been fully understood. The genetic mutation of complement genes, autoantibodies to complement factor $\mathrm{H}$ or $\mathrm{B}$, and autoantibodies that stabilize alternative pathway conversion have already been described ${ }^{9,10}$. The association of DDD with mutation of $\mathrm{CFH}$ gene and factor $\mathrm{H}$ related protein 5 (FHRP5) is well established, but most patients with DDD, as well as our patient, do not have disease-causing mutations in $\mathrm{CFH}^{6}$. Our patient had the most common polymorphism of factor $\mathrm{H}, \mathrm{H} 402$ allele, that is associated with DDD, as well as age-related macular degeneration ${ }^{11,12}$. The exact mechanism of such a pattern is not known, but it is assumed to be due to the loss of protective binding of factor $\mathrm{H}$ to GBM if $\mathrm{H} 402$ allele is present ${ }^{13}$. On comparison of the risk $\mathrm{H} 402$ allele and protective Y402 allele, consistently greater alternative complement pathway activity is associated with DDD risk alleles ${ }^{14}$. In some cases, streptococcal infection appears to be a trigger for DDD in genetically predisposed individuals, but the exact mechanism is still speculated ${ }^{15}$.

Blood pressure control, minimization of proteinuria, and treatment of dyslipidemia are the recommended strategies of treatment. In case of a more aggressive disease, glucocorticosteroids and mycophenolate mofetil are suggested as a therapeutic strategy ${ }^{16}$. Evidence for a beneficial effect of eculizumab is considered but the response may be related to a specific etiology of the C3 deposits ${ }^{17,18}$. Plasma exchange should be considered for patients with factor $\mathrm{H}$ mutation to provide them with functionally intact factor $\mathrm{H}^{6}$. Although the prognosis of children with DDD is still poor, our patient restored kidney function without the need for additional corticosteroid/cytostatic treatment. It takes constant monitoring in order to timely respond to preserve renal function as long as possible. Because the causative mutation was not established, screening of family members for DDD was not performed.

\section{Conclusion}

We believe that proper diagnosis and individual management of such specific glomerulopathy are im- portant to avoid or at least slow down progression to end-stage renal disease. Therefore, personalized approach to each individual patient should be applied.

\section{References}

1. Noris M, Remuzzi G. Glomerular diseases dependent on complement activation, including atypical hemolytic uremic syndrome, membranoproliferative glomerulonephritis, and C3 glomerulopathy: Core Curriculum 2015. Am J Kidney Dis. 2015;66(2):359-75. doi: 10.1053/j.ajkd.2015.03.040

2. Sethi S, Fervenza FC. Membranoproliferative glomerulonephritis: pathogenetic heterogeneity and proposal for a new classification. Semin Nephrol. 2011;31(4):341-8. doi: 10.1016/ j.semnephrol.2011.06.005

3. Barbour TD, Ruseva MM, Pickering MC. Update on C3 glomerulopathy. Nephrol Dial Transplant. 2016;31(5):717-25. doi: https://doi.org/10.1093/ndt/gfu317

4. Angioi A, Fervenza FC, Sethi S, et al. Diagnosis of complement alternative pathway disorders. Kidney Int. 2016;89:27888. doi: 10.1016/j.kint.2015.12.003

5. Lu DF, Moon M, Lanning LD, McCarthy AM, Smith RJH. Clinical features and outcomes of 98 children and adults with dense deposit disease. Pediatr Nephrol.2012;27(5):773-81. doi: 10.1007/s00467-011-2059-7

6. Smith RJ, Alexander J, Barlow PN, Botto M, Cassavant TL, Cook HT, et al. New approaches to the treatment of dense deposit disease. J Am Soc Nephrol. 2007;18(9):2447-56. doi: 10.1681/ASN.2007030356

7. Servais A, Noël LH, Roumenina LT, Le Quintres M, Ngo S, Dragon-Durey MA, et al. Acquired and genetic complement abnormalities play a critical role in dense deposit disease and other C3 glomerulopathies. Kidney Int. 2012;82(4):454-64. doi: 10.1038/ki.2012.63

8. Corvillo F, López-Trascasaa M. Acquired partial lipodystrophy and C3 glomerulopathy: dysregulation of the complement system as a common mechanism. Nefrologia. 2018;38:258-66. doi: 10.1016/j.nefroe.2018.04.002

9. Barbour TD, Pickering MC, Cook HT. Dense deposit disease and C3 glomerulopathy. Semin Nephrol. 2013;33(6):493-507. doi: 10.1016/j.semnephrol.2013.08.002

10. Strobel S, Zimmering M, Papp K, Prechl J, Józsi M. Anti-factor $\mathrm{B}$ autoantibody in dense deposit disease. Mol Immunol. 2010;47(7-8):1476-83. doi: 10.1016/j.molimm.2010.02.002

11. Edwards AO, Ritter R3 ${ }^{\text {rd }}$, Abel KJ, Manning A, Panhuysen C, Farrer LA. Complement factor $\mathrm{H}$ polymorphism and age-related macular degeneration. Science. 2005;308(5720):421-4. doi: 10.1126/science.1110189

12. Ziskind A, Bardien S, van der Merwe L, Webster AR. The frequency of the $\mathrm{H} 402$ allele of $\mathrm{CFH}$ and its involvement with age-related maculopathy in an aged Black African Xhosa pop- 
ulation. Ophthalmic Genet. 2008;29(3):117-9. doi: 10.1080/ 13816810802216472

13. Lau KK, Smith RJ, Kolbeck PC, Butani L. Dense deposit disease and the factor H H402 allele. Clin Exp Nephrol. 2008;12(3):228-32. doi: 10.1007/s10157-008-0031-z

14. Abrera-Abeleda MA, Nishimura C, Frees K, Jones M, Maga T, Katz LM, et al. Allelic variants of complement genes associated with dense deposit disease. J Am Soc Nephrol. 2011;22(8): 1551-9. doi: 10.1681/ASN.2010080795

15. Prasto J, Kaplan BS, Russo P, Chan E, Smith RJ, Meyers KE. Streptococcal infection as possible trigger for dense deposit disease (C3 glomerulopathy). Eur J Pediatr. 2014;173(6): 767-72. doi: 10.1007/s00431-013-2245-7
16. Rovin BH, Caster DJ, Cattran DC, Gibson KL, Hogan JJ, Moeller MJ, et al. Management and treatment of glomerular diseases (Part 2): Conclusions from a Kidney Disease: Improving Global Outcomes (KDIGO) Controversies Conference. Kidney Int. 2019;95(2):281. doi: https://doi.org/10.1016/j. kint.2018.11.008

17. Oosterveld MJ, Garrelfs MR, Hoppe B, Florquin S, Roelofs JJ, van den Heuvel LP, et al. Eculizumab in pediatric dense deposit disease. Clin J Am Soc Nephrol. 2015;10(10):1773-82. doi: 10.2215/CJN.01360215

18. Nester CM, Smith RJ. Treatment options for C3 glomerulopathy. Curr Opin Nephrol Hypertens. 2013;22(2):231-7. doi: 10.1097/MNH.0b013e32835da24c

Sažetak

\section{DIJETE S BOLEŠĆU GUSTIH DEPOZITA I SMANJENOM AKTIVNOŠĆU KLASIČNOG PUTA KOMPLEMENTA}

\section{Trutin, L. Oletić, D. Galešić Ljubanović, D. Turudić i D. Milošević}

Prikazujemo rijedak slučaj dječaka s nefritičkim sindromom u podlozi bolesti gustih depozita (dense deposit disease, DDD) s disfunkcijom alternativnog puta komplementa koja je objašnjena utvrđenim pozitivnim protutijelima na $\mathrm{C} 3$ nefritički faktor $(\mathrm{C} 3 \mathrm{NeF})$ i polimorfizmom gena za faktor $\mathrm{H}$ povezanog s DDD. Osmogodišnji dječak prezentirao se makroskopskom hematurijom, hipertenzijom i periorbitalnim edemima s ponavljano niskim vrijednostima C3 tijekom 8 tjedana praćenja. Pozitivno imunofluorescentno bojanje na $\mathrm{C} 3$ i negativno na sva ostala protutijela, poduprto gustim depozitima unutar glomerularne bazalne membrane na elektronskoj mikroskopiji, potvrdilo je dijagnozu DDD. Preliminarno ispitivanje aktivacije komplementa pokazalo je ukupnu nedostatnu aktivnost alternativnog puta i smanjenu aktivnost klasičnog puta komplementa, kao i neznatno pozitivan $\mathrm{C} 3 \mathrm{NeF}$, što govori u prilog dijagnozi DDD. Genetska analiza otkrila je polimorfizam gena za faktor $\mathrm{H}$ s povećanim rizikom za razvoj DDD. Suportivna terapija dovela je do zadovoljavajućeg oporavka bubrežne funkcije i normalizacije vrijednosti C3. S obzirom na lošu prognozu bolesti važan je pravilan pristup takvoj specifičnoj glomerulopatiji kako bi se odgodila progresija u završni stadij bubrežne bolesti.

Ključne riječi: Bolest gustib depozita; C3 glomerulopatija; Djeca; Nefritički sindrom 